\title{
Association of an ACSL1 gene variant with polyunsaturated fatty acids in bovine skeletal muscle
}

\author{
Philipp Widmann ${ }^{1}$, Karin Nuernberg ${ }^{2}$, Christa Kuehn ${ }^{1}$ and Rosemarie Weikard ${ }^{1 *}$
}

\begin{abstract}
Background: The intramuscular fat deposition and the fatty acid profiles of beef affect meat quality. High proportions of unsaturated fatty acids are related to beef flavor and are beneficial for the nutritional value of meat. Moreover, a variety of clinical and epidemiologic studies showed that particularly long-chain omega-3 fatty acids from animal sources have a positive impact on human health and disease.

Results: To screen for genetic factors affecting fatty acid profiles in beef, we initially performed a microsatellitebased genome scan in a $F_{2}$ Charolais $\times$ German Holstein resource population and identified a quantitative trait locus (QTL) for fatty acid composition in a region on bovine chromosome 27 where previously QTL affecting marbling score had been detected in beef cattle populations. The long-chain acyl-CoA synthetase 1 (ACSL1) gene was identified as the most plausible functional and positional candidate gene in the QTL interval due to its direct impact on fatty acid metabolism and its position in the QTL interval. ACSL1 is necessary for synthesis of long-chain acyl-CoA esters, fatty acid degradation and phospholipid remodeling. We validated the genomic annotation of the bovine ACSL1 gene by in silico comparative sequence analysis and experimental verification. Re-sequencing of the complete coding, exon-flanking intronic sequences, $3^{\prime}$ untranslated region ( $\left.3^{\prime} U T R\right)$ and partial promoter region of the ACSL1 gene revealed three synonymous mutations in exons 6, 7, and 20, six noncoding intronic gene variants, six polymorphisms in the promoter region, and four variants in the $3^{\prime}$ UTR region. The association analysis identified the gene variant in intron 5 of the ACSL1 gene (c.481-233A>G) to be significantly associated with the relative content of distinct fractions and ratios of fatty acids (e.g., n-3 fatty acids, polyunsaturated, n-3 long-chain polyunsaturated fatty acids, trans vaccenic acid) in skeletal muscle. A tentative association of the ACSL1 gene variant with intramuscular fat content indicated that an indirect effect on fatty acid composition via modulation of total fat content of skeletal muscle cannot be excluded.
\end{abstract}

Conclusions: The initial QTL analysis suggested the ACSL1 gene as a positional and functional candidate gene for fatty acid composition in bovine skeletal muscle. The findings of subsequent association analyses indicate that ACSL1 or a separate gene in close proximity might play a functional role in mediating the lipid composition of beef.

\section{Background}

In recent decades, the continuing accumulation of knowledge and the increasing number of reports providing evidence regarding the beneficial health effects of polyunsaturated fatty acids (PUFA) have attracted the attention of the medical and public community. Consumers are becoming increasingly aware of the relationships between diet and health and also of the

\footnotetext{
* Correspondence: weikard@fbn-dummerstorf.de

'Research Unit Molecular Biology, Leibniz Institute for Farm Animal Biology (FBN), Wilhelm-Stahl-Allee 2, Dummerstorf, 18196, Germany

Full list of author information is available at the end of the article
}

importance of the diet for general physical and mental wellbeing [1,2]. Many clinical and epidemiologic studies have indicated a positive impact of long-chain omega-3 fatty acids ( $n-3$ long-chain polyunsaturated fatty acids, n-3 LC-PUFA) on human health and disease. Beneficial effects of n-3 LC-PUFA are described in infant development, cancer, and cardiovascular diseases (e.g., [3-6]), lipid and glucose metabolism (e.g., [7-10]), inflammation (e.g., $[11,12])$, and more recently, in various mental illnesses including depression, attention-deficit hyperactivity disorder, and dementia (e.g.,[13]). It has been demonstrated that diets containing higher levels of $n-3$

\section{Biomed Central}


LC-PUFA [namely DHA (docosahexaenoic acid; C22:6n3) and EPA (eicosapentaenoic acid; C20:5n-3)], may reduce cardiovascular risk in diabetes by inhibiting platelet aggregation, improving lipid profiles, and reducing cardiovascular mortality. Thus, n-3 LC-PUFA were particularly recommended to people with diabetes and metabolic disorders associated to obesity $[5,14]$. Their beneficial health effects may be mediated through multiple distinct mechanisms, including alterations in cell membrane composition and function, gene expression, or eicosanoid biosynthesis $[15,16]$. It is known that $n-3$ LC-PUFA can exert important metabolic effects due to their ability to modulate the transcription of regulatory genes with function in lipid metabolism [17-21].

The n-3 LC-PUFA, like DHA and EPA, are particularly abundant in oily cold-water fish and seafood, however, they are also present in other animal products (e. g., ruminant meat and milk) but in lower concentrations. Increases of n-3 LC-PUFA content in the human diet can be achieved by dietary supplementation, but there is also a potential to alter the natural fatty acid (FA) profile in food from animals. FA composition of meat and milk reflects both, FA biosynthesis in the respective animal tissue and FA composition of ingested nutrients. A recent study showed that cattle and lambs fed grass-diet in the period before slaughter had an increased content of beneficial FAs in meat, and that subsequent moderate consumption of the respective meat had resulted in increased plasma and platelet $n-3$ LC-PUFA concentrations in healthy human individuals [22]. A ruminant diet on grass, which is rich in $\alpha$-linolenic acid (C18:3n-3, ALA) compared to cereal-based concentrate diet can influence the FA profile of meat in the desired direction and improve its nutritional value [23-25]. However, the link between nutritional intake of FAs and its subsequent concentration in skeletal muscle is stronger in monogastric animals (pigs, poultry) than in ruminants due to hydrogenation of dietary FAs in the rumen (e.g., [26]).

In addition to the environmental conditions, genetic factors may also have a substantial effect on the variability of FA composition in animal products, especially for ruminants [27]. Consequently, genetic selection and breeding of animals with favorably enriched n-3 LCPUFA content in skeletal muscle can provide a rich source of the desired beneficial FAs for the human diet. Therefore, it is necessary to elucidate the moleculargenetic background of fatty acid composition in bovine skeletal muscle for identifying the genes or gene variants favorable for human nutrition.

Numerous quantitative trait loci (QTL) affecting meat quality traits in cattle like marbling and FA composition have been identified on a variety of bovine chromosomes (http://www.animalgenome.org/cgi-bin/gbrowse/ bovine/), which enabled subsequent identification of positional candidate genes, which are located in the vicinity of identified QTL and have putative physiological functions regarding FA synthesis in skeletal muscle. These candidate genes for lipid-associated traits have been studied for their possible role regarding phenotypic variation observed between and within breeds. DNA variants in a variety of genes involved in lipid synthesis and FA metabolism have been found to influence FA composition in bovine muscle tissue and carcass (SCD1, [28-34], SREBP-1 [29], FASN [29,34-37], FABP4 and $L X R \alpha$ [38], GH [29], ACACA [39], myostatin [40,41], leptin [33]).

However, the biochemical processes and the molecular background affecting the genetic variability of the complex polygenic trait of FA composition are not yet completely understood, particularly with regard to European cattle breeds, because the majority of recent studies have been performed on the very specific genetic background of Japanese Black cattle.

Therefore, the aim of this study was to identify genetic factors affecting the variation of FA composition in bovine skeletal muscle. For our study, we took advantage of a unique $F_{2}$ resource population generated from the major European cattle breeds Charolais and German Holstein by means of embryo transfer and foster mothers [42]. In previous studies, this population had been shown to segregate for two major loci (NCAPG and $M S T N$ ) associated with prenatal and pubertal growth, postnatal body composition and general lipid deposition $[43,44]$.

\section{Results and discussion}

The animals from our resource cross population were kept and fed at standardized uniform conditions and slaughtered at the same age. Therefore, we can exclude exogenous factors due to differences in herd, age, feeding and gender. Consequently, differences in skeletal muscle fatness or FA composition should be due to differences in endogenous factors of the animals like the genetic background. The primary focus of our study was to discover phenotypic differences of FA composition in skeletal muscle between the individual animals of the resource population due to genetic variation.

\section{QTL analysis and identification of ACSL1 as a positional and functional candidate gene}

An initial QTL analysis in the Charolais $\times$ German Holstein cross population identified a QTL for FA composition on bovine chromosome 27 (BTA27) as exemplified for n-3 LC-PUFA in Figure 1. In our study, the trait n-3 LC-PUFA represents n-3 PUFA exceeding a carbon chain length of C18. The QTL interval corresponded to a region, where previously QTL affecting marbling had 


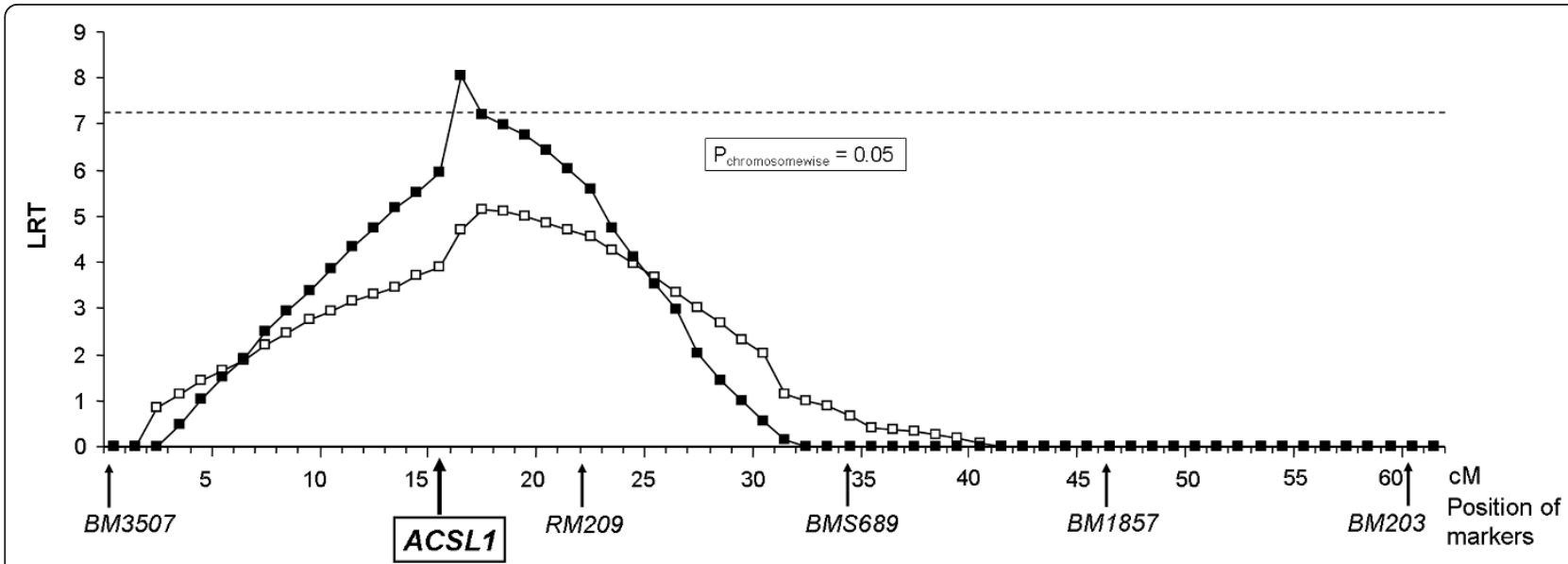

Figure 1 QTL for the relative content of $\mathbf{n}-\mathbf{3}$ long chain PUFA ( $\mathbf{n}-\mathbf{3}$ LC PUFA) on BTA27. Solid boxes: ACSL1 C.481-233A>G effect not included in the model, open boxes: ACSL1 C.481-233A>G included in the model as a fixed effect. LRT significance threshold is indicated by a dashed line $(\alpha=0.05: 7.23)$.

been detected in a Bos indicus $\times$ Bos taurus cross and two commercial US Angus populations [45,46]. The QTL explained 20.5\% variance in the model calculated as the relative reduction of the residual variance due to including the QTL in the model [47].

Furthermore, QTL for FA composition, myristic acid, (C14:0) and oleic acid (C18:1) content, have been reported in this chromosomal region in a Jersey $x$ Limousin back-cross cattle population [48]. In our study, the QTL interval affecting FA composition in skeletal muscle displayed a peak between 15 and $16 \mathrm{cM}$ on our genetic map of BTA27 corresponding to a genomic position at approximately $16 \mathrm{Mb}$ on the current bovine genome assembly of the chromosome (NCBI mapviewer, build 5.2, http://www.ncbi.nlm.nih.gov/projects/mapview $/$ map_search.cgi?taxid $=9913$ ).

Based on its chromosomal position and integration in biochemical pathways of lipid metabolism, we identified the acyl-CoA synthetase long-chain family member 1 (ACSL1) gene as the most plausible positional and functional candidate gene underlying the QTL with effect on FA composition on BTA27. The ACSL1 gene is located exactly under the peak of the QTL interval. Its protein, the ACSL1 enzyme, is known to catalyze the first step of activation of long-chain (LC) FAs by converting them into $\mathrm{LC}$ acyl CoA thioesters for channeling towards chain elongation, triacylglyceride synthesis or FA oxidation [49]. ACSL1 has a key function in both the synthesis of cellular lipids and FA degradation, and is also necessary for phospholipid remodeling [50]. Due to its physiological biochemical function, it can be suggested that ACSL1 plays an important role in lipid metabolism, insulin resistance and obesity. Recently, a study in humans reported that a gene variant located in intron 1 of the ACSL1 gene can influence the metabolic syndrome risk (characterized by insulin resistance, dyslipidaemia, abdominal obesity and hypertension associated to type 2 diabetes), and that this ACSL1 genotype-dependent effect can be modulated by dietary PUFA intake suggesting a genenutrient interaction [51].

\section{Structure analysis and screening for polymorphisms of the ACSL1 gene}

Although sequences for the ACSL1 gene and protein were deposited in the bovine genome databases, we found inconsistencies regarding the structural annotation of the gene in the bovine genome assemblies. A correct and conclusive structural gene annotation is a prerequisite for subsequent screening for gene variants and analysis of their functional relevance. Therefore, the first step of our study focused on the experimental confirmation of the structure of the ACSL1 gene on the genomic and cDNA level. Experimental verification by RT-PCR, re-sequencing and comparative sequence analyses confirmed the genomic annotation of the bovine ACSL1 gene in the alternate UMD_3.1 genome assembly (Figure 2), which is in contrast to the reference genome assembly Btau4.2 (http://www.ncbi.nlm.nih.gov/projects/ mapview/map_search.cgi?taxid = 9913).

Re-sequencing of DNA from pools and individuals differing in IMF content and $\Delta^{9}$ desaturase activity index included a total of $8.5 \mathrm{~Kb}$ of genomic DNA. Comparative sequence analysis revealed a total of 19 single nucleotide polymorphisms (SNPs) in the targeted gene regions (Table 1). Three synonymous exonic (exons 6,7 and 20), six intronic (introns 5, 6, 9, 13, 16 and 20), six SNPs in the promoter region and four SNPs in the 3'UTR of the bovine ACSL1 gene were detected (Figure 2, Table 1). Eleven out of these SNPs identified in our 


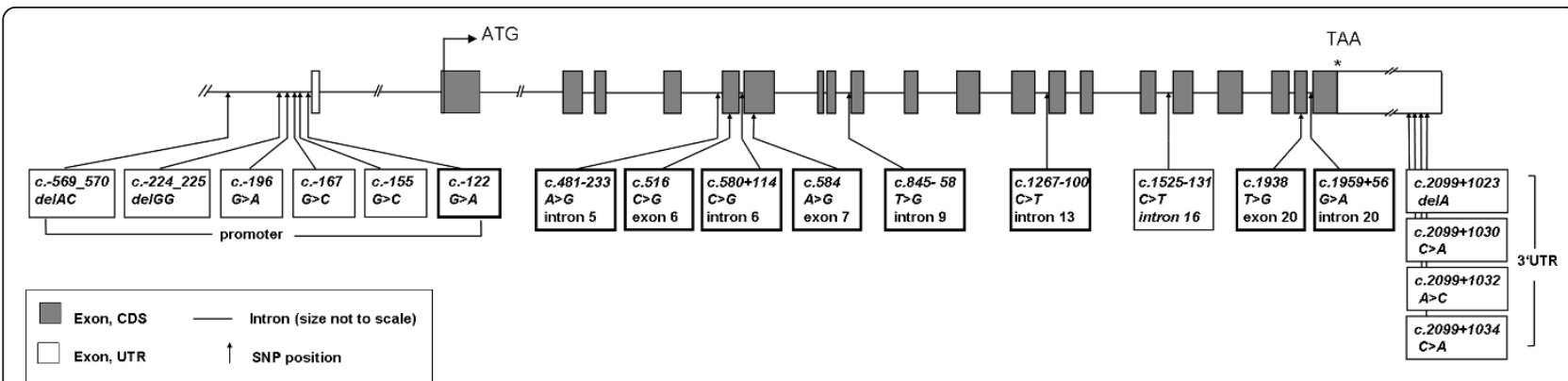

Figure 2 Structure of the bovine ACSL1 gene and detection of polymorphic sites. Reference mRNA sequence: NM_001076085.1. SNPS included in the association analysis are bold framed.

study were novel and not previously represented in the SNP database (version 133) at NCBI.

\section{Association of ACSL1 gene variants with PUFA profile in skeletal muscle}

The association analysis included all exonic and intronic ACSL1 gene variants (except for the one in intron 16) and one SNP in the promoter region, which were identified by re-sequencing and validated by genotyping in the Charolais $\times$ German Holstein resource population. The nine SNPs analyzed in the Holstein $\times$ Charolais cross bred population showed a minor allele frequency $\geq 0.2$ in the analyzed data set (Table 1). Intragenic linkage disequilibrium (LD) analysis revealed a strong LD between the SNPs in intron 20, exon 20, intron 13 and intron $9\left(\mathrm{r}^{2}>0.9\right)$, whereas there was only a moderate LD $\left(0.5<r^{2}<0.6\right)$ between these SNPs and the one in intron 5 .

Table 1 Identified SNPs within the ACSL1 locus and positions on the bovine genome assemblies

\begin{tabular}{|c|c|c|c|c|c|c|}
\hline $\begin{array}{l}\text { SNP ID } \\
\text { relative to } \\
\text { coding } \\
\text { sequence* }\end{array}$ & $\begin{array}{l}\text { Gene } \\
\text { region }\end{array}$ & $\begin{array}{l}\text { Variation relative to } \\
\text { reference sequence }\end{array}$ & $\begin{array}{c}\text { Position on } \\
\text { NW_001494406.2 } \\
\text { (Btau4.2) }\end{array}$ & $\begin{array}{c}\text { Position on } \\
\text { NW_003104605.1 } \\
\text { (UMD_3.1) }\end{array}$ & $\begin{array}{c}\text { Allele } \\
\text { frequency }\end{array}$ & $\begin{array}{l}\text { SNP accession number } \\
\text { (dbSNP, NCBI ss\#) }\end{array}$ \\
\hline c.-569_570del AC & Promoter & Indel TG & 1918795 & 389858 & Not analyzed & ss469271165 \\
\hline c.-224_225del & Promoter & Indel $(C)_{5-7}$ & 1918451 & 389615 & Not analyzed & ss469271166 \\
\hline C. $-196 \mathrm{G}>\mathrm{A}$ & Promoter & $C>T$ & 1918422 & 3894586 & Not analyzed & ss469271167 \\
\hline c. $-167 G>C$ & Promoter & $C>G$ & 1918393 & 3894557 & Not analyzed & ss469271168 \\
\hline c. $-151 G>C$ & Promoter & $C>G$ & 1918377 & 3894541 & Not analyzed & ss469271169 \\
\hline c. $-122 \mathrm{G}>\mathrm{A}$ & Promoter & $C>T$ & 1918348 & 3894512 & $0.67(\mathrm{G}) / 0.33(\mathrm{~A})$ & ss469271170 \\
\hline c. $481-233 A>G$ & Intron 5 & $\mathrm{~T}>\mathrm{C}$ & 1876389 & 3852106 & $0.73(\mathrm{~A}) / 0.27(\mathrm{G})$ & ss469271171 \\
\hline C. $516 \mathrm{C}>\mathrm{G}$ & Exon 6 & $\mathrm{G}>\mathrm{C}$ & 1876121 & 3852284 & $0.57(\mathrm{C}) / 0.43(\mathrm{G})$ & ss469271172 \\
\hline c. $580+114 C>G$ & Intron 6 & $\mathrm{G}>\mathrm{C}$ & 1875943 & 3852552 & $0.33(\mathrm{C}) / 0.67(\mathrm{G})$ & ss469271173 \\
\hline c. $584 A>G$ & Exon 7 & $\mathrm{~T}>\mathrm{C}$ & 1875838 & 3852001 & $0.07(\mathrm{G}) / 0.94(\mathrm{~A})$ & ss469271174 \\
\hline c. $845-58 \mathrm{~T}>\mathrm{G}$ & Intron 9 & $A>C$ & 1871919 & 3848082 & $\begin{array}{c}0.75(\mathrm{~T}) / 0.21(\mathrm{G}) \\
5\end{array}$ & s\$469271175 \\
\hline c. $1267-100 C>T$ & Intron 13 & $G>A$ & 1864210 & 3840373 & $0.24(\mathrm{~T}) / 0.76(\mathrm{C})$ & ss469271176 \\
\hline C.1525-131C>T & Intron 16 & $G>A$ & 1859370 & 3835533 & Not analyzed & ss469271177 \\
\hline c. $1938 \mathrm{~T}>\mathrm{G}$ & Exon 20 & $A>C$ & Not annotated & 3831586 & $0.75(\mathrm{~T}) / 0.25(\mathrm{G})$ & ss469271178 \\
\hline c. $1959+56 G>A$ & Intron 20 & $C>T$ & Not annotated & 3831509 & $0.24(\mathrm{~A}) / 0.76(\mathrm{G})$ & ss469271179 \\
\hline $\begin{array}{c}\text { c.2099+1023del } \\
\text { A }\end{array}$ & $3^{\prime} U T R$ & Indel A & 1853870 & 3829944 & Not analyzed & ss469271180 \\
\hline $\begin{array}{l}c .2099+1030 \\
C>A\end{array}$ & $3^{\prime} U T R$ & $C>A$ & 1853863 & 3829937 & Not analyzed & ss469271181 \\
\hline $\begin{array}{c}\text { c. } 2099+1032 \\
A>C\end{array}$ & 3'UTR & $A>C$ & 1853861 & 3829935 & Not analyzed & ss469271182 \\
\hline $\begin{array}{l}\text { c. } 2099+1034 \\
\text { C>A }\end{array}$ & $3^{\prime} U T R$ & $C>A$ & 1853859 & 3829933 & Not analyzed & ss469271183 \\
\hline
\end{tabular}

*SNP nomenclature according to the translation start codon ATG, reference sequence NM_001076085.1. SNPs marked in bold were included in the association analysis. Genomic positions of the SNPs were inferred from the current versions of the refererence and alternative bovine genome assemblies Btau4.2 and UMD_3.1 available at NCBI (http://www.ncbi.nlm.nih.gov/genome/guide/cow/index.html). 
The association analysis with intragenic ACSL1 SNPs revealed that the SNP located in intron 5 of the ACSL1 gene $(c .481-233 A>G)$ showed the most significant associations with FA composition in skeletal muscle. The gene variant $A C S L 1$ c.481-233A>G was significantly associated with the relative content of distinct fractions of unsaturated FAs, n-3 FA, PUFA, n-3 LC-PUFA and docosapentaenoic fatty acid (DPA) as well as with the absolute content of total FA, MUFA, and trans vaccenic acid (C18:1trans-11) in M. longissimus dorsi (Table 2). The results revealed that the $c .481-233 A$ allele of this gene variant is strongly associated with a higher relative level of n-3 FA, PUFA, DPA, and n-3 LC-PUFA. In contrast, the c.481-233A allele showed a decreasing effect on content of C18:1trans-11, total FA, and MUFA, and tended to be associated with a lower IMF content in skeletal muscle compared to the c.481-233G allele. The c.481-233A allele had a higher freqeuncy (73\%) in the analyzed population compared to the alternative allele (27\%).

Although the $c .481-233 A$ allele tends to be associated with a slightly lower total IMF content, the relative content of the FA fractions, n-3 FA, PUFA, DPA, and n-3 LC-PUFA, known to exert health-beneficial effects in humans is highly increased indicating a higher nutritional value for beef originating from animals with the favorable ACSL1 allele.
The strongest allelic effect of the ACSL1 c.481$233 A>G$ locus was observed for n-3 FA content. This trait also includes the polyunsaturated $\mathrm{C} 18$ fatty acids, $\alpha$-linolenic acid (ALA, C18:3n-3) and stearidonic acid (C18:4n-3). The n-3-FA content is different to the trait n-3 LC-PUFA, which exclusively comprises n-3 FA with a chain length $>$ C18. As an essential FA, ALA cannot be synthesized by mammalian species and must be obtained from the diet. The ALA concentration in skeletal muscle, therefore, could be linked to the dietary absorption. However, the standardized concentratebased feeding regimen in our study provides uniform feeding conditions for the animals. ALA is the precursor for the n-3 FA pathway [52] by serving as parent FA for the synthesis of stearidonic acid and n-3 LC-PUFA (EPA, DPA, and DHA) via sequential steps of desaturation and/or chain-elongation. The association of ACSL1 c.481-233A $>G$ with DPA and with n-3 LC-PUFA (containing n-3 FA exceeding a chain length of $\mathrm{C} 18$ ) could suggest that a substantial proportion of their precursor ALA might be activated and channeled to chain elongation processes.

The trait PUFA comprises both FA types, the n- 6 and n-3 FA. The ACSL1 c.481-233A>G variant showed no significant impact on n-6 FA content and thus, its association with PUFA could be due to its effect on the trait's component n-3 FA.

Table 2 Association of the SNP in intron 5 of the ACSL1 gene (c.481-233A>G) with variation in intramuscular fatty acid composition and fat content

\begin{tabular}{|c|c|c|c|c|c|c|c|c|c|c|c|c|c|}
\hline \multirow[b]{2}{*}{ Trait* } & \multicolumn{7}{|c|}{ Model without IMF as covariate } & \multicolumn{6}{|c|}{ Model with IMF as covariate } \\
\hline & LRT & $\begin{array}{l}\mathrm{p}- \\
\text { value }\end{array}$ & $\begin{array}{l}\text { Effect allele } \\
\text { A }\end{array}$ & SE & $\begin{array}{l}\text { Effect allele } \\
\text { G }\end{array}$ & SE & $\begin{array}{l}\operatorname{Var}[\%] \\
* *\end{array}$ & LRT & $\begin{array}{l}\mathrm{p}- \\
\text { value }\end{array}$ & $\begin{array}{l}\text { Effect allele } \\
\text { A }\end{array}$ & SE & $\begin{array}{l}\text { Effect allele } \\
\text { G }\end{array}$ & SE \\
\hline Total FA [mg] ${ }^{* \&}$ & 6.2 & 0.0130 & 3.70 & 0.07 & 3.88 & 0.07 & & 3.8 & 0.0507 & & & & \\
\hline MUFA $[\mathrm{mg}]^{* \&}$ & 5.9 & 0.0154 & 3.29 & 0.08 & 3.48 & 0.09 & & 2.9 & 0.0874 & & & & \\
\hline $\mathrm{n}-3$ FA $[\%]^{* *}$ & 9.7 & $0.0018^{\mathrm{a}}$ & 0.16 & 0.05 & 0.01 & 0.06 & 11.4 & 5.8 & 0.0159 & 0.42 & 0.04 & 0.36 & 0.04 \\
\hline PUFA [\%]*\# & 7.1 & $0.0079^{b}$ & 1.12 & 0.05 & 0.98 & 0.06 & 3.5 & 3.9 & 0.0477 & & & & \\
\hline $\mathrm{n}-3$ LC PUFA [\%] $]^{\#}$ & 6.7 & $0.0099^{b}$ & 0.24 & 0.03 & 0.16 & 0.04 & 3.4 & 3.5 & 0.0628 & & & & \\
\hline$\underset{* \&}{C 18: 1 \text { trans }-11[\mathrm{mg}]}$ & 10.5 & $0.0012^{\mathrm{a}}$ & 1.31 & 0.10 & 1.63 & 0.12 & 6.5 & 8.1 & $0.0045^{\mathrm{a}}$ & 0.86 & 0.09 & 1.07 & 0.10 \\
\hline C22:5n-3 [\%] ${ }^{\#}$ & 7.2 & 0.0071 & 0.16 & 0.02 & 0.11 & 0.03 & 3.6 & 5.9 & 0.0150 & 0.27 & 0.02 & 0.23 & 0.02 \\
\hline PUFA/SFA* & 7.3 & $0.0069^{b}$ & -0.79 & 0.06 & -0.94 & 0.07 & 3.6 & 4.2 & 0.0407 & & & & \\
\hline $\mathrm{P} / \mathrm{S}^{*}$ & 6.7 & $0.0099^{b}$ & -1.02 & 0.05 & -1.15 & 0.06 & 3.2 & 3.2 & 0.0758 & & & & \\
\hline LA/ALA* & 4.9 & 0.0265 & 1.03 & 0.03 & 0.97 & 0.03 & & 1.9 & 0.1720 & & & & \\
\hline IMF [\%] & 3.1 & 0.0776 & 1.11 & 0.18 & 1.42 & 0.21 & 1.7 & & & & & & \\
\hline
\end{tabular}

*Trait data log-transformed, \&absolute content of fatty acids ( $\mathrm{mg} / 100 \mathrm{~g}$ of skeletal muscle), " relative content of fatty acids (percentage of the respective fatty acid fraction relative to total fatty acid amount)

LTR: likelihood ratio test, p: significancy of allelic effects, Var: variance explained, SE: standard error, ${ }^{\mathrm{a}} \mathrm{q}-\mathrm{value}<0.05,{ }^{\mathrm{b}} \mathrm{q}-\mathrm{value}<0.1,{ }^{*} \% \%$ variance in the model calculated as the relative reduction of the residual variance due to including the SNP in the model [47].

Allelic effects of the ACSL1 SNP (c.481-233A>G) on different FA fractions: $n-3$ fatty acids (n-3 FA $=$ C18:3n-3 + C18:4n-3 + C20:5n-3 + C22:5n-3 + C22:6n-3), polyunsaturated fatty acids (PUFA $=n-3$ FA + n-6 FA [C18:2n-6 + C18:3n-6 + C20:2n-6 + C20:3n-6 + C20:4n-6 + C22:2n-6 + C22:4n-6]), n-3 long-chain PUFA (n-3 LCPUFA $=$ C20:3n-3 + C22:6n-3 + C22:5n-3 + C20:5n-3), total FA, mono-unsaturated fatty acids (MUFA), docosapentaenoic fatty acid (DPA, C22:5n-3), trans vaccenic acid (TVA, C18:1trans-11) and the ratios: PUFA/SFA (saturated fatty acids $=$ C12:0 + C14:0 + C16:0 + C17:0 + C18:0 + C20:0 + C24:0), P/S (C18:2 n-6 + C18:3 n-3/ C14:0 + C16:0 + C18:0), LA/ALA (C18:2 n-6/C18:3 n-3), and the intramuscular fat content (IMF). 
Interestingly, the $A C S L 1$ gene variant c.481-233A>G that affected FA profiles in bovine skeletal muscle had no significant influence on the ratio $n-6 / n-3$ FA in this tissue. Considering the standardized uniform feeding regimen in our study, this result could support the findings from other studies, which indicate that the $n-6 / n-3$ FA ratio may be affected more by feeding than by genetics $[53,54]$. In contrast, we found the ACSL1 gene variant c.481-233A>G to be associated with the LA/ALA (C18:2 n-6/C18:3 n-3) ratio. Furthermore, we observed significant associations of this gene variant with the ratios PUFA/SFA and $\mathrm{P} / \mathrm{S}$ in our study, both representing characteristics of meat quality and widely used to evaluate the nutritional value of meat fat content. Again, the c.481-233A allele revealed an increasing effect on these ratios compared to the c.481-233G allele.

In contrast to the increasing effect associated with the c.481-233A allele on the relative content of the FA fractions, n-3 FA, PUFA, DPA, and n-3 LC-PUFA, and the PUFA/SFA and $P / S$ ratios, we observed a decreasing effect of this allele on the absolute content of the trans vaccenic acid C18:1trans-11 in skeletal muscle in our study. This effect was in concert with the associated parallel decrease in total FA and MUFA content in the tissue. The effect on C18:1trans-11 is of particular interest, because trans vaccenic acid is a precursor of conjugated linoleic acid (CLAcis-9, trans-11) generation. CLAs are believed to have several important physiological functions, including anti-carcinogenic, anti-atherogenic, immunomodulating, growth and lean body mass promoting effects [55]. Thus, targeted selection of cattle carrying the homozygous $c .481-233 A / c .481-233 A$ genotype in the ACSL1 gene would possibly be accompanied by detrimental effects on the CLA profile in skeletal muscle.

There is the open question, whether the significant effects of the ACSL1 gene variant c.481-233A>G on FA composition were due to general fatness differences in skeletal muscle, which is supported by several QTL for marbling in the targeted chromosomal region, or whether the effects were associated with the ACSL1 gene variant $c .481-233 A>G$. Alternatively, the effects of this gene variant might modulate the accumulation of specific FAs in skeletal muscle. To address this issue, we extended our association analysis and fitted IMF as a covariate in the model. When adjusting for IMF (Table 2 ), the association of the ACSL1 gene variant c.481$233 A>G$ with absolute content of trans vaccenic acid in skeletal muscle remained significant, whereas the other associations dropped below a stringent threshold of statistical significance (Bonferroni $\mathrm{q}<0.1$ ) and were only tentatively significant (e.g., for relative content of $n-3$ FA and DPA). Thus, we cannot exclude that variants in the bovine ACSL1 gene may exert a substantial effect on total intramuscular fat content, which indirectly affects intramuscular composition of specific FA fractions. However, as the results for trans vaccenic acid demonstrate, it is suggested that there are also direct effects associated with the $A C S L 1$ gene variant c.481-233A>G on intramuscular content of specific FAs.

\section{Conclusions}

Due to our observation that the $c .481-233 A>G$ SNP in intron 5 of the ACSL1 gene cannot fully explain the QTL variance (Figure 1), we conclude that this gene variant is presumably not causal, but in LD to another not yet detected polymorphism in its close vicinity affecting FA composition in bovine skeletal muscle. Presumably, these effects are not exclusively the consequence of variation in intramuscular fat content, but due to effects on specific FA. Prior to selective breeding of cattle carrying the desired genotype of the ACSL1 gene variant c.481-233A>G in order to produce meat with specific FA profiles, the association between $c .481$ $233 A>G$ and FA composition has to be confirmed in the particular target cattle population.

Nevertheless, our results indicate that the ACSL1 gene might play a functional role in mediating the FA composition in bovine skeletal muscle and provide a basis to further elucidate the function of the ACSL1 gene and its coordinated network with genes integrated in FA metabolism to dissect the molecular background of lipid composition of beef.

\section{Methods}

\section{Animals and phenotypes}

The generation of the Charolais $\times$ German Holstein resource cross population (SEGFAM), details regarding feeding and housing of the animals analyzed in our study, have been previously described $[43,44]$. The animals were kept under standardized environmental and feeding conditions in barn facilities at the Leibniz Institute for Farm Animal Biology (FBN). After birth, the calves were fed a milk/replacer/hay/concentrate diet ad libitum until day 121 . Thereafter, the animals received a feed ration of concentrates and chaffed hay with a hay to concentrate ratio of $1: 3$ and an energy content of 12.7 MJ ME/kg dry matter fed ad libitum until slaughter. The animals were kept in a tight stall barn with individual daily feed recording. At the age of 18 months (547 days of age), the male animals were slaughtered, and a detailed dissection of the carcass was performed. A wide range of phenotypic data related to beef production and beef quality including FA composition were recorded including FA composition of selected skeletal muscles.

Analysis of FA composition of lipids involving 26 different FAs in skeletal muscle (M. longissimus dorsi) was 
determined for $156 \mathrm{~F}_{2}$ bulls using capillary gas chromatography as described previously [56]. The absolute amount of FAs in skeletal muscle was determined from $2 \mathrm{~g}$ of skeletal muscle and calculated as mg/100 g tissue. The relative content of individual fatty acids was calculated as percentage of the total amount of FAs extracted. Based on the data obtained for individual fatty acids, sums of specific fatty acid fractions were calculated: saturated fatty acids (SFA), unsaturated fatty acids (UFA), monounsaturated fatty acids (MUFA), trans fatty acids (TFA), n-3 fatty acids (n-3 FA), n-6 fatty acids (n6 FA), polyunsaturated fatty acids (PUFA) and n-3 longchain PUFA (n-3 LC-PUFA). Furthermore, the ratios n6/n-3 FA, MUFA/SFA, PUFA/SFA, P/S and LA/ALA as well as four different $\Delta^{9}$ desaturase indices [57] were calculated. Intramuscular fat (IMF) content (percentage in $100 \mathrm{~g}$ tissue) was ascertained in M. longissimus dorsi by FoodScan Lab (FOSS) as described previously [56]. The phenotypic traits for FA composition of IMF included in our study are summarized in Table 3.

\section{QTL analysis}

An initial QTL scan comprising 244 microsatellite markers [58] for variation of FA composition in skeletal muscle had pinpointed a region on bovine chromosome 27 (BTA27) with effect on n-3 PUFA content in skeletal muscle. Five microsatellite markers located on BTA27 (BM3507, RM209, BMS689, BM1857, BM203) had been genotyped in all $733 \mathrm{P}_{0}, \mathrm{~F}_{1}$, and $\mathrm{F}_{2}$ individuals of the Charolais $\times$ German Holstein resource population.

The respective QTL interval pointed to a chromosomal region on BTA27 harboring the acyl-CoA synthetase long-chain family member 1 (ACSL1) gene according to the sequence assembly of the chromosome. Therefore, in a second step of our analysis, nine intragenic ACSL1 SNPs (Figure 1) were added to the initial marker set. All microsatellite markers and all genotyped ACSL1 SNPs were included to calculate a genetic map using CRIMAP Version 2.50 [59], incorporating modifications by Ian Evans and Jill Maddox (University of Melbourne). The resulting genetic map was applied in the QTL analyses with a variance component QTL model as implemented in Qxpak [60] and essentially as described previously [43]:

$$
\mathrm{y}=\mathbf{F} b+\mathbf{Z} u+\mathbf{Q} g+e ;
$$

where $\mathrm{y}$ is a vector of phenotypes, $b$ is a vector of the fixed effects (slaughter year, NCAPG I442M genotype), $u$ is the vector of individual infinitesimal polygenic effects, $g$ is a vector of the additive QTL effects not fixed within founder breeds; $\mathbf{F}, \mathbf{Z}$ and $\mathbf{Q}$ represent the incidence matrices for the fixed, polygenic and the QTL effect, respectively, and $e$ is the vector of random residuals. An MCMC algorithm was used to calculate identity-by-descent probabilities as implemented in Qxpak. The NCAPG I442M mutation was included in the model, because previous analyses had shown a major effect of the mutation on carcass lipid deposition and growth in the resource population [44].

Statistical significance of the QTL analyses was tested by a likelihood-ratio test (LRT). Significance thresholds for the LRT were determined according to [61], considering one chromosome with a length of $0.6 \mathrm{M}$ and an average marker density of $0.1 \mathrm{M}$. The significance thresholds for false positive results with $\alpha=0.05$ and $\alpha$ $=0.01$ correspond to LRT values > 7.2 and LRT > 10.2, respectively.

\section{Structural analysis of the ACSL1 gene}

The coding sequence of the bovine ACSL1 gene is represented by the reference mRNA sequence NM_001076085.1, which spans 3690 bp and is located on BTA27.

At the beginning of our study, the previous bovine genome assembly Btau4.0 and the current reference assembly Btau4.2 available at NCBI (http://blast.ncbi.nlm.nih.gov/ Blast.cgi?PAGE_TYPE=BlastSearch\&PROG_DEF=blastn\&BLAST_PROG_DEF $=$ megaBlast\&SHOW_DEFAULTS $=$ on\&BLAST_SPEC $=$ OGP_9913_10708, [62]) annotated the bovine ACSL1 gene with a total of 19 protein-coding exons. In silico sequence analysis of the respective mRNA and protein sequences (NM_001076085.1 and NP_001069553) revealed that parts of the sequences could not be aligned to the bovine genome reference assembly Btau4.2. This indicated an incomplete annotation of the bovine ACSL1 gene. However, in the alternative bovine genome assembly Bos_taurus_UMD3.1 (ftp://ftp.cbcb.umd.edu/pub/data/assembly/ Bos_taurus/Bos_taurus_UMD_3.1/, [63]) integrated into the recent bovine genome assembly, Build 5.2, at NCBI (http://www.ncbi.nlm.nih.gov/projects/mapview/map_search.cgi?taxid=9913), the bovine ACSL1 gene was annotated with a total of 21 protein-coding exons, which is also in agreement with the earlier bovine genome assembly, version Btau3.1. Comparative sequence analysis between gene and protein sequences of the bovine ACSL1 gene and those of the orthologous human counterparts (NM_001995.2 and NP_001986.2) and the current human genome assembly Hsa37.2 (http://blast.ncbi.nlm.nih.gov/ Blast.cgi?PAGE_TYPE=BlastSearch\&PROG_DEF =blastn\&BLAST_PROG_DEF $=$ megaBlast\&SHOW_DEFAULTS $=$ on\&SHOW_DEFAULTS $=$ on \&BLAST_SPE$\left.\mathrm{C}=\mathrm{OGP} \_9606 \_9558\right)$ showed that the mRNA and amino acid sequences of both species display a high similarity ( $88 \%$ and $91 \%$ identity, respectively), which supported the annotation of the current Bos_taurus_UMD3.1 and the earlier Btau3.1 assemblies. 
Table 3 Phenotypic traits characterizing fatty acid composition in skeletal muscle

\begin{tabular}{|c|c|c|c|c|c|}
\hline Trivial name & Abbreviation & $\begin{array}{r}\text { Mean of absolute } \\
\text { content }(\mathrm{mg} / 100 \mathrm{~g})\end{array}$ & SD & $\begin{array}{r}\text { Mean of relative } \\
\text { content (\%) } \\
\end{array}$ & SD \\
\hline Lauric acid & $\mathrm{C} 12: 0$ & $2.83^{*}$ & 1.80 & 0.10 & 0.04 \\
\hline Myristoleic acid & C14:1 cis-9 & 18.53 & 17.85 & 0.62 & 0.31 \\
\hline Myristic acid & C14:0 & $92.12^{*}$ & 65.50 & $3.10^{*}$ & 0.66 \\
\hline Palmitoleic acid & C16:1 cis-9 & $109.33^{*}$ & 76.59 & 3.73 & 0.83 \\
\hline Palmitic acid & C16:0 & $823.94^{*}$ & 490.88 & 28.77 & 1.86 \\
\hline Heptadecenoic acid & C17:1 cis-10 & $23.48^{*}$ & 12.51 & 0.85 & 0.18 \\
\hline Margaric acid & C17:0 & $34.94^{*}$ & 18.13 & $1.26^{*}$ & 0.25 \\
\hline Stearic acid & C18:0 & $373.40^{*}$ & 199.95 & $4.96^{*}$ & 1.80 \\
\hline Oleic acid & C18:1 cis-9 & $981.37^{*}$ & 578.52 & 34.35 & 2.60 \\
\hline Vaccenic acid & C18:1cis-11 & $43.60^{*}$ & 30.60 & 13.41 & 1.65 \\
\hline trans Vaccenic acid & C18:1trans-11 & $28.40^{*}$ & 20.18 & $1.52^{*}$ & 0.33 \\
\hline Linoleic acid (LA) & $C 18: 2 n-6$ & $121.45^{*}$ & 29.94 & $0.99^{*}$ & 0.43 \\
\hline Linolelaidic acid & C18:2trans-9, trans-12 & $4.11^{*}$ & 3.39 & 0.11 & 0.13 \\
\hline Conjugated linoleic acid & CLAcis-9, trans-11 & $5.99^{*}$ & 4.73 & 0.20 & 0.09 \\
\hline$\alpha$-Linolenic acid (ALA) & C18:3n-3 & 12.99 & 4.97 & $0.50^{*}$ & 0.14 \\
\hline Stearidonic acid (SDA) & $C 18: 4 n-3$ & 2.70 & 3.36 & 0.15 & 0.10 \\
\hline Arachidic acid & C20:0 & 2.94 & 1.90 & 0.11 & 0.06 \\
\hline Eisosenoic acid & $C 20: 1 n-9$ & $4.21^{*}$ & 2.80 & 0.35 & 0.15 \\
\hline Eisosatrienoic acid (ETE) & $C 20: 3 n-3$ & $8.15^{*}$ & 1.86 & $0.11^{*}$ & 0.05 \\
\hline Arachidonic acid (AA) & $C 20: 4 n-6$ & 33.89 & 7.60 & $1.48^{*}$ & 0.74 \\
\hline Timnodonic acid, EPA & $C 20: 5 n-3$ & $2.41^{*}$ & 0.70 & $0.14^{*}$ & 0.03 \\
\hline Erucic acid & C22:1n-9 & $0.46^{*}$ & 0.24 & $0.02^{*}$ & 0.01 \\
\hline Adrenic acid & $C 22: 4 n-6$ & 6.20 & 1.53 & 0.28 & 0.13 \\
\hline Clupadonic acid, DPA & $C 22: 5 n-3$ & $6.51^{*}$ & 1.34 & $0.26^{*}$ & 0.11 \\
\hline Cervonic acid, DHA & $C 22: 6 n-3$ & 0.92 & 0.45 & 0.04 & 0.03 \\
\hline Lignoceric acid & C24:0 & 0.82 & 0.44 & $0.03^{*}$ & 0.02 \\
\hline$\Sigma$ Saturated fatty acids & SFA & $1352.06^{*}$ & 777.93 & 47.55 & 2.38 \\
\hline$\Sigma$ Unsaturated fatty acids & UFA & $1463.62^{*}$ & 777.61 & 52.45 & 2.38 \\
\hline$\sum$ Polyunsaturated fatty acids & PUFA & $208.34^{*}$ & 44.62 & $8.57^{*}$ & 3.02 \\
\hline$\Sigma$ Monounsaturated fatty acids & MUFA & $1208.85^{*}$ & 726.67 & $42.19^{*}$ & 3.16 \\
\hline$\sum$ trans fatty acids & TFA & $43.92^{*}$ & 24.70 & 1.58 & 0.47 \\
\hline$\sum n-3$ fatty acids & $n-3 F A$ & 24.75 & 6.42 & $1.01^{*}$ & 0.35 \\
\hline$\sum \mathrm{n}-3$ long-chain PUFA & n-3 LCPUFA & 9.58 & 2.21 & $0.42^{*}$ & 0.20 \\
\hline$\sum n-6$ fatty acids & $n-6 F A$ & $167.28^{*}$ & 34.88 & 6.94 & 2.64 \\
\hline$\sum \mathrm{n}-6$ long-chain PUFA & n-6 LCPUFA & 40.09 & 8.62 & 1.78 & 0.85 \\
\hline$\sum$ Total fatty acids & FA & $2743.81^{*}$ & 1524.08 & & \\
\hline Ratio n-6/n-3 & $n-6 / n-3$ & 6.96 & 1.42 & & \\
\hline Ratio MUFA/SFA & MUFA/SFA & 0.89 & 0.09 & & \\
\hline Ratio PUFA/SFA & PUFA/SFA & $0.18^{*}$ & 0.07 & & \\
\hline Ratio P/S & $\mathrm{P} / \mathrm{S}$ & $0.12^{*}$ & 0.05 & & \\
\hline Ratio C18:2n-6/C18:3n-3 & LA/ALA & $9.86^{*}$ & 2.51 & & \\
\hline$\Delta^{9}$-desaturase index MUFA & $\triangle 9 M U F A$ & 46.39 & 2.56 & & \\
\hline$\Delta^{9}$-desaturase index C14 & $\Delta 9 C 14$ & 16.31 & 6.65 & & \\
\hline$\Delta^{9}$-desaturase index C16 & $\Delta 9 C 16$ & 11.40 & 2.08 & & \\
\hline$\Delta^{9}$-desaturase index $C 18$ & $\Delta 9 C 18$ & 72.16 & 3.34 & & \\
\hline Intramuscular fat content & IMF & & & 2.56 & 1.13 \\
\hline
\end{tabular}

SD: standard deviation

*Data displaying distributions significantly different from normality $(p<0.01)$ were log-transformed.

$\mathrm{SFA}=\mathrm{C} 12: 0+\mathrm{C} 14: 0+\mathrm{C} 16: 0+\mathrm{C} 17: 0+\mathrm{C} 18: 0+\mathrm{C} 20: 0+\mathrm{C} 24: 0$

MUFA $=$ C14:1 + C16:1 + C17:1 + C18:1 + C20:1 + C22:1 + C18:1 cis-9 + C18:1 cis-11 + C18:1 trans-11

UFA $=$ MUFA + PUFA 


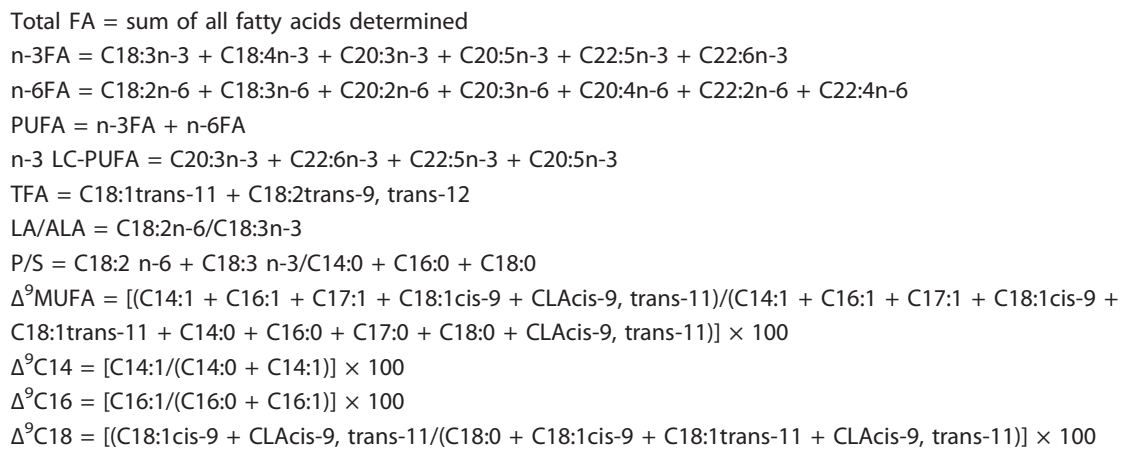

An experimental confirmation of the bovine ACSL1 gene structure was required because of the inconsistent annotation of the ACSL1 gene. Therefore, fragments completely covering the coding region of the gene and the 5' und 3' UTRs, including the respective critical gene fragments with discordant structure annotation, were validated in our study. Exon-flanking primers (Table 4) were derived from the sequence contigs NW_001494406.2 and NW_930554.1 and used for PCRamplification with genomic DNA and cDNA. Genomic DNA was isolated from blood leucocytes using standard methods. The cDNA was prepared from liver tissue of a lactating cow. Total RNA extraction and cDNA synthesis by reverse transcription were performed as described recently [43]. To amplify cDNA fragments of the ACSL1 gene, PCR was performed with cDNA using gene-fragment specific primers (Table 4). The PCRamplicons were isolated from agarose gels using the NucleoSpin ${ }^{\circledR}$ Extract II kit (Macherey \& Nagel) and sequenced with PCR primers using BigDye $^{\odot}$ sequencing chemistry on a capillary sequencer (MEGABACE, GE Healthcare).

\section{Screening for polymorphisms in the ACSL1 gene}

Screening for polymorphisms was carried out by resequencing and covered the complete coding sequence, exon-flanking intronic regions, the 5' and 3' UTRs and 724 bp of the promoter of the ACSL1 gene. DNA primer pairs for PCR amplification and sequencing were designed based on genomic contig sequences (NW_001494406.2 and NW_930554.1) and the mRNA sequence (NM_001076085.1), respectively (Table 4).

Four genomic DNA pools consisting of selected animals from the Charolais $\times$ Holstein resource population differing in their intramuscular fat content and index of delta 9-desaturase were established and subjected to screening for gene variants by comparative re-sequencing. The IMF pools contained DNA from sampling time- and pedigree-matched animals with high $(\mathrm{n}=5$, $4.93 \pm 1.73 \%)$ and low $(\mathrm{n}=7,1.78 \pm 0.21 \%)$ IMF. The $\Delta^{9}$ desaturase index pools consisted of DNA from sampling time- and pedigree-matched animals with a high $(\mathrm{n}=7 ; 50.87 \pm 0.89)$ or low $(\mathrm{n}=6,43.86 \pm 0.95)$ $\Delta^{9}$ desaturase index. Furthermore, two genomic DNA samples from control individuals and two individual DNA samples originating from extreme animals displaying the lowest (1.63\%) and highest (6.09\%) IMF were included to validate the results received from the pools.

Genomic DNA was isolated from blood leucocytes using standard methods. PCR with exon-flanking primers (Table 4) was performed with a total of $60 \mathrm{ng}$ genomic DNA as described above. The generated PCR products were purified using the peqGOLD Cycle-Pure Kit (PEQLAB) according to the manufacturer's instructions and sequenced. Sequencing was performed on a capillary sequencer (MEGABACE, GE Healthcare) with primers used for targeted PCR amplification. To identify variable DNA positions, the sequences were analyzed meticulously by visual inspection of the sequencing profiles from DNA-pools and individuals' DNA and by sequence alignment to the reference cDNA sequence (NM_001076085.1) as well as to the respective bovine genome sequences. All SNPs identified by sequencing of DNA pools were verified by single sample resequencing.

\section{SNP Genotyping}

Out of the identified 19 ACSL1 SNPs (see Table 3, Figure 1), nine were genotyped in the Charolais $\times$ German Holstein resource population: Two exonic SNPs $(c .516 C>G, c .1938 T>G)$ and five intronic SNPs (c.481$233 A>G, c .580+114 C>G, c .845-58 T>G, c .1267-100 C>T$, c. $1959+56 G>A$ ) were genotyped on an Illumina Beadstation [64] as part of a targeted 384. SNP GoldenGate assay. The SNP in exon $7(c .584 A>G)$ was analyzed using a PCR-RFLP assay with primers for amplification of the targeted region (Table 4) and the restriction enzyme SacI (Fermentas). The promoter SNP c.$122 G>A$ was genotyped by a Tetra-ARMS PCR assay [65] and validated by direct sequencing. The respective primers are given in Table 4. The NCAPG I442M mutation was genotyped by PCR-RFLP [43]. 
Table 4 Primer sequences for the bovine ACSL1 gene applied for annotation confirmation, screening for polymorphisms and genotyping

\begin{tabular}{|c|c|c|c|c|c|c|}
\hline Primer & Sequence $\left(5^{\prime} \rightarrow 3^{\prime}\right)$ & Gene region & $\begin{array}{l}\text { Amplicon } \\
\text { (bp) }\end{array}$ & $\begin{array}{l}\text { Position in reference } \\
\text { sequence }\end{array}$ & $\begin{array}{l}\text { AccNo. of reference } \\
\text { sequence }\end{array}$ & Application* \\
\hline $\begin{array}{l}\text { ACSL1_F1 } \\
\text { ACSL1_R1 }\end{array}$ & $\begin{array}{l}\text { CCGAGCCCCAACCGAGAC } \\
\text { TGGACGCTGTTCTTGAGTGGTG }\end{array}$ & $\begin{array}{l}\text { intron } 1 \\
\text {-promoter }\end{array}$ & 844 & $\begin{array}{l}1918181-1918198 \\
1919003-1919024\end{array}$ & NW_001494406.2 & SNP \\
\hline $\begin{array}{l}\text { ACSL1_E1_F3 } \\
\text { ACSL1_E1SF }\end{array}$ & $\begin{array}{l}\text { GACCCGAGCCCCAACCGAG } \\
\text { GTTGAGCCACCACAATTTACTC }\end{array}$ & $\begin{array}{l}\text { intron } 1 \\
\text {-promoter }\end{array}$ & 497 & $\begin{array}{l}1918178-1918196 \\
1918674-1918653\end{array}$ & NW_001494406.2 & SNP \\
\hline $\begin{array}{l}\text { ACSL1_E1SR } \\
\text { ACSL1_R1 }\end{array}$ & $\begin{array}{l}\text { GGACTGCCCTGGATTTCACAAG } \\
\text { TGGACGCTGTTCTTGAGTGGTG }\end{array}$ & promoter & 413 & $\begin{array}{l}1918612-1918633 \\
1919003-1919024\end{array}$ & NW_001494406.2 & SNP \\
\hline $\begin{array}{l}\text { ACSL1_F2 } \\
\text { ACSL1_R2 }\end{array}$ & $\begin{array}{l}\text { TCGCTGCTGAAGTCCTGTCTG } \\
\text { GCTCTAATGCCCCCGTTGATG }\end{array}$ & exon 2 & 501 & $\begin{array}{l}1897290-1897310 \\
1897770-1897790\end{array}$ & NW_001494406.2 & SNP \\
\hline $\begin{array}{l}\text { ACSL1_F3 } \\
\text { ACSL1_R3 }\end{array}$ & $\begin{array}{l}\text { TTGCGTGGGAGAGAGTTGTG } \\
\text { TCAGGTGGAGGATTTATGTCAG }\end{array}$ & exon 3 & 384 & $\begin{array}{l}1882758-1882777 \\
1883120-1883141\end{array}$ & NW_001494406.2 & SNP \\
\hline $\begin{array}{l}\text { ACSL1_F4 } \\
\text { ACSL1_R4 }\end{array}$ & $\begin{array}{l}\text { GCATCCACACTCCATAGAAAC } \\
\text { AATAAAGAAGCAAAACTCAGACC }\end{array}$ & exon 4 & 345 & $\begin{array}{l}1881998-1882018 \\
1882320-1882342\end{array}$ & NW_001494406.2 & SNP \\
\hline $\begin{array}{l}\text { ACSL1_F5 } \\
\text { ACSL1_R5 }\end{array}$ & $\begin{array}{l}\text { ATGAAAGGGAAAAGTGAAAGTG } \\
\text { CTTGAGTTGGACCTGATGCTG }\end{array}$ & exon 5 & 457 & $\begin{array}{l}1878288-1878309 \\
1878724-1878744\end{array}$ & NW_001494406.2 & SNP \\
\hline $\begin{array}{l}\text { ACSL1_F6 } \\
\text { ACSL1_R6 }\end{array}$ & $\begin{array}{l}\text { CGGCTGGAAGTAAAGAGACAC } \\
\text { TTGTGTTCTTCATCCTCCTITC }\end{array}$ & exon 6 & 574 & $\begin{array}{l}1875840-1875860 \\
1876392-1876413\end{array}$ & NW_001494406.2 & SNP \\
\hline $\begin{array}{l}\text { ACSL1_F7 } \\
\text { ACSL1_R7 }\end{array}$ & $\begin{array}{l}\text { GTTCTCTITACAGGACCAG } \\
\text { CAGGGATGCTITACTTACTC }\end{array}$ & exon 7 & 600 & $\begin{array}{l}1875542-1875561 \\
1876122-1876141\end{array}$ & NW_001494406.2 & SNP \\
\hline $\begin{array}{l}\text { ACSL1_F8_9 } \\
\text { ACSL1_R8_9 }\end{array}$ & $\begin{array}{l}\text { TGGGTGATGTAAATGTGTGAGG } \\
\text { ATGATAGGAATGGCAGTGGAGAC }\end{array}$ & $\begin{array}{l}\text { exons } \\
8-9\end{array}$ & 750 & $\begin{array}{l}1872567-1872588 \\
1873294-1873316\end{array}$ & NW_001494406.2 & SNP \\
\hline $\begin{array}{l}\text { ACSL1_F10 } \\
\text { ACSL1_R10 }\end{array}$ & $\begin{array}{l}\text { ATCTGTATTTCAGGTACTGTTTC } \\
\text { GTTATGGGCTTCTCTCACG }\end{array}$ & exon 10 & 287 & $\begin{array}{l}1871656-1871678 \\
1871923-1871942\end{array}$ & NW_001494406.2 & SNP \\
\hline $\begin{array}{l}\text { ACSL1_F11 } \\
\text { ACSL1_R11 }\end{array}$ & $\begin{array}{l}\text { TACACACTTGAACTTACCAG } \\
\text { TGTGCTCTGAAATAAATGG }\end{array}$ & exon 11 & 314 & $\begin{array}{l}1869171-1869190 \\
1869466-1869484\end{array}$ & NW_001494406.2 & SNP \\
\hline $\begin{array}{l}\text { ACSL1_F12 } \\
\text { ACSL1_R12 }\end{array}$ & $\begin{array}{l}\text { TCTGTATTGTGCCTTCTGATG } \\
\text { GGAAACTGGGCTGAAATGC }\end{array}$ & exon 12 & 371 & $\begin{array}{l}1866801-1866821 \\
1867153-1867171\end{array}$ & NW_001494406.2 & SNP \\
\hline $\begin{array}{l}\text { ACSL1_F13 } \\
\text { ACSL1_R13 }\end{array}$ & $\begin{array}{l}\text { TCTCACACAATAAAGGGGTAGG } \\
\text { TCCACATCTTCACCAACACTC }\end{array}$ & exon 13 & 516 & $\begin{array}{l}1864669-1864690 \\
1865164-1865184\end{array}$ & NW_001494406.2 & SNP \\
\hline $\begin{array}{l}\text { ACSL1_F14 } \\
\text { ACSL1_R14 }\end{array}$ & $\begin{array}{l}\text { AAGCCGCCCAGGAATAACAC } \\
\text { TGCCACAAACCCACGACACT }\end{array}$ & exon 14 & 516 & $\begin{array}{l}1863888-1863907 \\
1864384-1864403\end{array}$ & NW_001494406.2 & SNP \\
\hline $\begin{array}{l}\text { ACSL1_F15 } \\
\text { ACSL1_R15 }\end{array}$ & $\begin{array}{l}\text { GACTTGTGTTATTTCTGCCTG } \\
\text { TGGGCTGAGGTITCTAATCC }\end{array}$ & exon 15 & 524 & $\begin{array}{l}1862774-1862795 \\
1863278-1863297\end{array}$ & NW_001494406.2 & SNP \\
\hline $\begin{array}{l}\text { ACSL1_F16 } \\
\text { ACSL1_R16 }\end{array}$ & $\begin{array}{l}\text { TGCTGAGAAGTGGCTGGTTAC } \\
\text { CATGAGAACAGGGCTTATTGG }\end{array}$ & exon 16 & 247 & $\begin{array}{l}1860135-1860155 \\
1860361-1860381\end{array}$ & NW_001494406.2 & SNP \\
\hline $\begin{array}{l}\text { ACSL1_F17 } \\
\text { ACSL1_R17 }\end{array}$ & $\begin{array}{l}\text { ATGCGAGGGAGAAAGAGG } \\
\text { CCGCTAACAAAAAGAACAGTG }\end{array}$ & exon 17 & 427 & $\begin{array}{l}1859039-1859056 \\
1859445-1859465\end{array}$ & NW_001494406.2 & SNP \\
\hline $\begin{array}{l}\text { ACSL1_F18 } \\
\text { ACSL1_R18 }\end{array}$ & $\begin{array}{l}\text { GGCAAACTTCCCATTACACTG } \\
\text { GACTCCTTCATCCCTTCTCTG }\end{array}$ & exon 18 & 512 & $\begin{array}{l}1857386-1857406 \\
1857877-1857897\end{array}$ & NW_001494406.2 & SNP \\
\hline $\begin{array}{l}\text { ACSL1_F19_20 } \\
\text { ACSL1_R19_20 }\end{array}$ & $\begin{array}{l}\text { GCCAAAGCACACCACTCTC } \\
\text { CGAAGCAGATAATAAGGAACTAC }\end{array}$ & exons 19-20 & 517 & $\begin{array}{l}139425-139443 \\
139919-139941\end{array}$ & NW_930554.1 & SNP \\
\hline $\begin{array}{l}\text { ACSL1_F21 } \\
\text { ACSL1_R21 }\end{array}$ & $\begin{array}{l}\text { CACCCGCCTITGTAACTG } \\
\text { GTCCTGATTCTGTCCTGATGTC }\end{array}$ & exon 21 & 548 & $\begin{array}{l}138819-138836 \\
139345-139366\end{array}$ & NW_930554.1 & SNP \\
\hline $\begin{array}{l}\text { ACSL1_UTR_F31 } \\
\text { ACSL1_UTR_R3 }\end{array}$ & $\begin{array}{l}\text { AAACCCTCTGGTCCTCTTGCG } \\
\text { CAATGGCAGGAAGGGAGGGAG }\end{array}$ & exon 21 & 404 & $\begin{array}{l}138633-138653 \\
139016-139036\end{array}$ & NW_930554.1 & SNP \\
\hline $\begin{array}{l}\text { ACSL1_UTR_F2 } \\
\text { ACSL1_UTR_R21 }\end{array}$ & $\begin{array}{l}\text { GAGTTTCCAGATTCCTATGTCC } \\
\text { CCTGTTACCCTCCCTTCCCTG }\end{array}$ & exon 21 & 650 & $\begin{array}{l}137966-137988 \\
138595-138615\end{array}$ & NW_930554.1 & SNP \\
\hline $\begin{array}{l}\text { ACSL1_UTR_F11 } \\
\text { ACSL1_UTR_R1 }\end{array}$ & $\begin{array}{l}\text { ATGCGACTGCTGACATGAAAAAC } \\
\text { AAATAAATGCTCTTCTGTCGTAATG }\end{array}$ & exon 21 & 527 & $\begin{array}{l}137530-137552 \\
138032-138056\end{array}$ & NW_930554.1 & SNP \\
\hline $\begin{array}{l}\text { ACSL1_E1_F3 } \\
\text { ACSL1_E1_R2 }\end{array}$ & $\begin{array}{l}\text { GACCCGAGCCCCAACCGAG } \\
\text { GCTCGTAGGCTGCAGCGAG }\end{array}$ & $\begin{array}{l}\text { intron 1- } \\
\text { promoter }\end{array}$ & 220 & $\begin{array}{l}1918178-1918196 \\
1918379-1918397\end{array}$ & NW_001494406.2 & GT \\
\hline $\begin{array}{l}\text { ACSL1_F7 } \\
\text { ACSL1_R7 }\end{array}$ & $\begin{array}{l}\text { GTTCTCTITTACAGGACCAG } \\
\text { CAGGGATGCTITACTTACTC }\end{array}$ & exon 7 & 600 & $\begin{array}{l}1875542-1875561 \\
1876122-1876141\end{array}$ & NW_001494406.2 & $\begin{array}{c}\text { GT } \\
(\text { PCR-RFLP) }\end{array}$ \\
\hline $\begin{array}{l}\text { ACSL1_E1_F5 } \\
\text { ACSL1_E1_R3 } \\
\text { ACSL1_E1_F7_T } \\
\text { ACSL1_E1_R8_C }\end{array}$ & $\begin{array}{l}\text { GGAGGGAACTCGGGGAGCC } \\
\text { AGGGCGGGGCTGAGACGG } \\
\text { GCTATTIAAGGGTGCCGCCGT } \\
\text { GCAGCCAGCTCTCGGAAGTAG }\end{array}$ & promoter & $\begin{array}{l}451 \\
316 \\
175\end{array}$ & $\begin{array}{l}1918052-1918070 \\
1918485-1918502 \\
1918328-1918348 \\
1918348-1918368\end{array}$ & NW_001494406.2 & $\begin{array}{c}\text { GT } \\
\text { (Tetra-ARMS } \\
\text { PCR) }\end{array}$ \\
\hline
\end{tabular}


Table 4 Primer sequences for the bovine ACSL1 gene applied for annotation confirmation, screening for polymorphisms and genotyping (Continued)

\begin{tabular}{llccc}
\hline ACSL1_E1_F2 & CGGAGGAGACTGTGGCTTAG & exons & 505 & NM_001076085.1 \\
ACSL1_E5_R1 & CTGAGCGAAGATGCCAATAAAC & $1-5$ & $521-543$ & CDNA \\
ACSL1_E5_F1 & CAGTTATTGGCATCTTCGCTC & exons & 649 & $519-541$ \\
ACSL1_E12_R2 & GGAAGATGGTGGGTGAAGG & $5-12$ & $1148-1168$ \\
ACSL1_E11_F2 & CCATATGTTGAGAGAGTTGTAG & exons 11-18 & 735 & $1046-1069$ \\
ACSL1_E18_R1 & ATGTACTCCCCCTGTGCCAG & & $1761-1781$ \\
ACSL1_E17_F2 & CTGGATAAAGACGGCTGGTTG & exons 17-21 & 399 & $1665-1686$ \\
ACSL1_E21_R2 & GAGTTCAGGGTGGAGATAGATG & & $2042-2064$ \\
ACSL1_E21_R3 & GTCAAACTCCCCTCCGCTTC & exons 17-21 & 540 & $2185-2205$ \\
ACSL1_E21_R4 & CAGAAAGAGCAAAGTCCTAACC & & NM_001076085.1 & NM_001076085.1 \\
\hline
\end{tabular}

* cDNA: analysis of cDNA structure, RT: reverse transcription, GT: genotyping, SNP: screening for polymorphisms

\section{Association analysis}

Prior to association analysis, we tested whether the phenotypic data of the individual traits were normally distributed using the Shapiro Wilk test. For those data displaying distributions significantly different from normality $(\mathrm{P}<0.01)$, we performed natural log $(\ln )$ transformation, and the log-transformed data were subjected to association analysis. The respective data are indicated in Tables 2 and 3.

The BTA27 marker haplotypes of the individuals of the resource population were estimated by a Markov chain Monte Carlo (MCMC) algorithm implemented in Qxpak [60]. The corresponding haplotypes were submitted to pairwise LD analysis calculating $\mathrm{r}^{2}$ values using PowerMarker V3.25 [66].

Subsequently to the QTL analyses, association analyses were performed between ACSL1 gene SNPs and the absolute and relative FA composition traits in $M$. longissimus dorsi. The following model testing for LD as implemented in Qxpak [60] was applied:

$$
y_{i}=a_{p}+\sum_{k} \sum_{h} \lambda_{i k h} g_{k}+\sum_{m} \sum_{n} \lambda_{i m n} g_{m}+u_{i}+e_{i h k m n p}
$$

where $y_{i}$ is the record of individual $i, a_{p}$ is the fixed effect of slaughter year $\mathrm{p}, \lambda_{\text {ihk }}$ is an indicator variable for the NCAPG I442M locus, which is 1 when the allele at the $\mathrm{h}^{\text {th }}$ haplotype ( 1 or 2 ) of the $\mathrm{i}^{\text {th }}$ individual is 1 and otherwise $0, \lambda_{\text {imn }}$ is a respective indicator variable for the specific ACSL1 SNP, $\mathrm{u}_{\mathrm{i}}$ is the infinitesimal genetic effect of individual $\mathrm{i}, \mathrm{g}_{\mathrm{k}}$ and $\mathrm{g}_{\mathrm{m}}$ are the respective allelic effects for NCAPG I442M and the ACSL1 $\mathrm{SNP}$, and $\mathrm{e}_{\mathrm{ihkmnp}}$ is the residual. Analogous to the QTL analyses, the NCAPG I442M mutation was included in the model, because previous analyses had shown a major effect of the mutation on carcass lipid deposition and growth in the resource population [44]. A likelihood-ratio test (likelihood of model with both loci vs. likelihood of model with NCAPG I442M) was applied to test for statistical significance. In order to dissect whether the association of the respective ACSL1 variant with intramuscular FA composition is solely due to indirect effects on IMF or a consequence of direct effects on the specific FA accumulation, we extended the model and fitted IMF as an additional covariate. A Bonferroni correction was calculated (q-value) to account for testing several SNPs in order to avoid false positive associations. The q-values thresholds of 0.05 and 0.1 , respectively, indicate an experiment-wise significant or suggestive association, respectively. Finally, an additive fixed effect of the SNP in intron 5 was added in the QTL model described above to test whether this SNP might explain the QTL variance at the identified position on BTA27.

\section{Abbreviations}

(SCD1): stearoyl-Coenzyme A desaturase 1; (SREBP-1): sterol regulatory element binding protein 1; (FASN): fatty acid synthase; (FABP4): fatty acid binding protein 4; ( $L X R a)$ : liver $X$ receptor alpha; $(G H)$ : growth hormone; (ACACA): acetyl-CoA carboxylase alpha; (NCAPG): non-SMC condensin I complex; subunit G, (MSTN): myostatin.

\section{Acknowledgements and Funding}

Skillful technical assistance of Annett Eberlein, Astrid Kühl, Marlies Fuchs, Birgit Jentz, Maria Dahm, Antje Lehmann and Simone Wöhl is thankfully acknowledged. We thank the German Federal Ministry of Education and Research (BMBF) for the financial support of this work within the scope of the FUGATO QUALIPID project (FKZ 0313391C). Also, we thank our colleagues at the FBN Dummerstorf involved in the generation and care of the SEGFAM F2 resource population for their continuous support of our work and Jill Maddox (University of Melbourne, Australia) for providing the modified CRIMAP version 2.50 .

\section{Author details}

${ }^{1}$ Research Unit Molecular Biology, Leibniz Institute for Farm Animal Biology (FBN), Wilhelm-Stahl-Allee 2, Dummerstorf, 18196, Germany. ${ }^{2}$ Research Unit Muscle Biology and Growth, Leibniz Institute for Farm Animal Biology (FBN), Wilhelm-Stahl-Allee 2, Dummerstorf, 18196, Germany.

\section{Authors' contributions}

PW participated in screening for polymorphisms, genotyping and statistical analysis. KN carried out fatty acid analysis. CK conceived the study and performed statistical analysis. RW performed gene structure analysis and screening for polymorphisms. CK and RW wrote the manuscript. All authors read and approved the final manuscript.

Received: 6 June 2011 Accepted: 11 November 2011

Published: 11 November 2011 


\section{References}

1. Scollan N, Hocquette JF, Nuernberg K, Dannenberger D, Richardson I, Moloney A: Innovations in beef production systems that enhance the nutritional and health value of beef lipids and their relationship with meat quality. Meat Sci 2006, 74:17-33.

2. Ward OP, Singh A: Omega-3/6 fatty acids: Alternative sources of production. Process Biochem 2005, 40:3627-3652.

3. Nettleton JA, Katz R: $n-3$ long-chain polyunsaturated fatty acids in type 2 diabetes: A review. J Am Diet Assoc 2005, 105:428-440

4. Cicero AFG, Ertek S, Borghi C: Omega-3 Polyunsaturated Fatty Acids: Their Potential Role in Blood Pressure Prevention and Management. Curr VasC Pharmacol 2009, 7:330-337.

5. Griffin BA: How relevant is the ratio of dietary $n-6$ to $n-3$ polyunsaturated fatty acids to cardiovascular disease risk? Evidence from the OPTILIP study. Curr Opin Lipidol 2008, 19:57-62.

6. Russo GL: Dietary n-6 and n-3 polyunsaturated fatty acids: From biochemistry to clinical implications in cardiovascular prevention. Biochem Pharmacol 2009, 77:937-946.

7. Harris WS, Miller M, Tighe AP, Davidson MH, Schaefer EJ: Omega-3 fatty acids and coronary heart disease risk: Clinical and mechanistic perspectives. Atherosclerosis 2008, 197:12-24

8. Flachs P, Rossmeisl M, Bryhn M, Kopecky J: Cellular and molecular effects of $n-3$ polyunsaturated fatty acids on adipose tissue biology and metabolism. Clin Sci 2009, 116:1-16.

9. Lombardo YB, Hein G, Chicco A: Metabolic syndrome: Effects of n-3 PUFAs on a model of dyslipidemia, insulin resistance and adiposity. Lipids 2007, 42:427-437.

10. Delarue J, Magnan C: Free fatty acids and insulin resistance. Curr Opin Clin Nutr Metab Care 2007, 10:142-148.

11. Browning LM, Krebs JD, Moore CS, Mishra GD, O'Connell MA, Jebb SA: The impact of long chain n-3 polyunsaturated fatty acid supplementation on inflammation, insulin sensitivity and CVD risk in a group of overweight women with an inflammatory phenotype. Diabetes Obes Metab 2007, 9:70-80.

12. Yusof HM, Miles EA, Calder P: Influence of very long-chain n-3 fatty acids on plasma markers of inflammation in middle-aged men. Prostaglandins Leukot Essent Fatty Acids 2008, 78:219-228.

13. Riediger ND, Othman RA, Suh M, Moghadasian MH: A Systemic Review of the Roles of n-3 Fatty Acids in Health and Disease. J Am Diet Assoc 2009, 109:668-679.

14. McEwen B, Morel-Kopp MC, Tofler G, Ward C: Effect of Omega-3 Fish Oil on Cardiovascular Risk in Diabetes. Diabetes Educator 2010, 36:565-584

15. Pachikian B, Neyrinck A, Cani P, Portois L, Deldicque L, Backer F, Bindels L, Sohet F, Malaisse W, Francaux M, Carpentier Y, Delzenne N: Hepatic steatosis in n-3 fatty acid depleted mice: focus on metabolic alterations related to tissue fatty acid composition. BMC Physiol 2008, 8:21.

16. Calder PC, Yaqoob P: Omega-3 polyunsaturated fatty acids and human health outcomes. Biofactors 2009, 35:266-272.

17. Jump DB: Dietary polyunsaturated fatty acids and regulation of gene transcription. Curr Opin Lipidol 2002, 13:155-164

18. Benatti P, Peluso G, Nicolai $R$, Calvani M: Polyunsaturated fatty acids: Biochemical, nutritional and epigenetic properties. J Am Coll Nutr 2004, 23:281-302.

19. Xu J, Nakamura MT, Cho HP, Clarke SD: Sterol regulatory element binding protein-1 expression is suppressed by dietary polyunsaturated fatty acids - A mechanism for the coordinate suppression of lipogenic genes by polyunsaturated fats. J Biol Chem 1999, 274:23577-23583.

20. Davidson $\mathrm{MH}$ : Mechanisms for the hypotriglyceridemic effect of marine omega-3 fatty acids. Am J Cardiol 2006, 98:271-331.

21. Hiller $R$, Herdmann A, Nuernberg K: Dietary $n-3$ fatty acids significantly suppress lipogenesis in bovine muscle and adipose tissue: $A$ functional genomics approach. Lipids 2011, , 46:: 557-67.

22. McAffee AJ, McSorley EM, Cuskelly GJ, Fearon AM, Moss BW, Beattie JAM, Wallace JMW, Bonham MP, Strain JJ: Red meat from animals offered a grass diet increases plasma and platelet n-3 PUFA in healthy consumers. Br J Nutr 2011, 105:80-89.

23. Dewhurst RJ, Scollan ND, Lee MRF, Ougham HJ, Humphreys MO: Forage breeding and management to increase the beneficial fatty acid content of ruminant products. Proc Nutr Soc 2003, 62:329-336.

24. Nuernberg K, Dannenberger D, Nuernberg G, Ender K, Voigt J, Scollan ND, Wood JD, Nute GR, Richardson Rl: Effect of a grass-based and a concentrate feeding system on meat quality characteristics and fatty acid composition of longissimus muscle in different cattle breeds. Livestock Prod Sci 2005, 94:137-147.

25. Leheska JM, Thompson LD, Howe JC, Hentges E, Boyce J, Brooks JC, Shriver B, Hoover L, Miller MF: Effects of conventional and grass-feeding systems on the nutrient composition of beef. J Anim Sci 2008, 86:3575-3585.

26. Lee MRF, Tweed JKS, Dewhurst RJ, Scollan ND: Effect of forage: concentrate ratio on ruminal metabolism and duodenal flow of fatty acids in beef steers. Anim Sci 2006, 82:31-40.

27. De Smet S, Raes K, Demeyer D: Meat fatty acid composition as affected by fatness and genetic factors: a review. Anim Res 2004, 53:81-98.

28. Barton L, Kott T, Bures D, Rehak D, Zahradkova R, Kottova B: The polymorphisms of stearoyl-CoA desaturase (SCD1) and sterol regulatory element binding protein-1 (SREBP-1) genes and their association with the fatty acid profile of muscle and subcutaneous fat in Fleckvieh bulls. Meat Sci 2010, 85:15-20.

29. Matsuhashi $T$, Maruyama $S$, Uemoto $Y$, Kobayashi $N$, Mannen $H$, Abe T, Sakaguchi S, Kobayashi E: Effectsof bovine fatty acid synthase, stearoylcoenzyme A desaturase, sterol regulatory element-binding protein 1, and growth hormone gene polymorphisms on fatty acid composition and carcass traits in Japanese Black cattle. J Anim Sci 2011, 89:12-22

30. Taniguchi M, Utsugi T, Oyama K, Mannen H, Kobayashi M, Tanabe Y, Ogino A, Tsuji S: Genotype of stearoyl-CoA desaturase is associated with fatty acid composition in Japanese Black cattle. Mamm Genome 2004, 15:142-148.

31. Ohsaki H, Tanaka A, Hoashi S, Sasazaki S, Oyama K, Taniguchi M, Mukai F, Mannen H: Effect of SCD and SREBP genotypes on fatty acid composition in adipose tissue of Japanese Black cattle herds. Anim Sci J 2009, 80:225-232.

32. Jiang Z, Tobey DJ, Daniels TF, Rule DC, MacNeil MD: Significant associations of stearoyl-CoA desaturase (SCD1) gene with fat deposition and composition in skeletal muscle. Int J Biol Sci 2008, 4:345-351.

33. Orru L, Cifuni G, Piasentier E, Corazzin M, Bovolenta S, Moioli B: Association analyses of single nucleotide polymorphisms in the LEP and SCD1 genes on the fatty acid profile of muscle fat in Simmental bulls. Meat SCi 2011, 87:344-348

34. Li C, Aldai N, Vinsky M, Dugan MER, McAllister TA: Association analyses of single nucleotide polymorphisms in bovine stearoyl-CoA desaturase and fatty acid synthetase genes with fatty acid composition in commercial cross-bred beef steers. Anim Genet 2011.

35. Zhang S, Knight TJ, Reecy JM, Beitz DC: DNA polymorphisms in bovine fatty acid synthase are associated with beef fatty acid composition. Anim Genet 2008, 39:62-70.

36. Uemoto $Y$, Abe $T$, Tameoka $N$, Hasebe $H$, Inoue $K$, Nakajima $H$, Shoji M, Kobayashi M, Kobayashi E: Whole-genome association study for fatty acid composition of oleic acid in Japanese Black cattle. Anim Genet 2011, 42:141-148.

37. Abe T, Saburi J, Hasebe H, Nakagawa T, Misumi S, Nade T, Nakajima $H$, Shoji M, Kobayashi M, Kobayashi E: Novel mutations in the FASN gene and their effects on fatty acid composition in Japanese Black beef. Biochem Genet 2009, 47:397-411.

38. Hoashi S, Hinenoya T, Tanaka A, Ohsaki H, Sasazaki S, Taniguchi M, Oyama K, Mukai F, Mannen H: Association between fatty acid compositions and genotypes of FABP4 and LXR-alpha in Japanese Black cattle. BMC Genet 2008, 9:84

39. Zhang S, Knight TJ, Reecy JM, Wheeler TL, Shackelford SD, Cundiff LV, Beitz DC: Associations of polymorphisms in the promoter I of bovine acetyl-CoA carboxylase-alpha gene with beef fatty acid composition. Anim Genet 2010, 41:417-420

40. Alexander LJ, Kuehn LA, Smith TPL, Matukumalli LK, Mote B, Koltes JE, Reecy J, Geary TW, Rule DC, MacNeil MD: A Limousin specific myostatin allele effects longissimus dorsi muscle area and fatty acid profiles in a Wagyu-Limousin F(2) population. J Anim Sci 2009, 87:1576-1581.

41. Wiener P, Wooliams JA, Frank-Lawale A, Ryan M, Richardson RI, Nute GR, Wood JD, Homer D, Williams JL: The effects of a mutation in the myostatin gene on meat and carcass quality. Meat Sci 2009, 83:127-134.

42. Kühn Ch, Bellmann O, Voigt J, Wegner J, Guiard V, Ender K: An experimental approach for studying the genetic and physiological background of nutrient transformation in cattle with respect to nutrient secretion and accretion type. Arch Anim Breed 2002, 45:317-330. 
43. Eberlein A, Takasuga A, Setoguchi K, Pfuhl R, Flisikowski K, Fries R, Klopp N, Furbass R, Weikard R, Kuhn C: Dissection of Genetic Factors Modulating Fetal Growth in Cattle Indicates a Substantial Role of the Non-SMC Condensin I Complex, Subunit G (NCAPG) Gene. Genetics 2009, 183:951-964.

44. Weikard R, Altmaier E, Suhre K, Weinberger KM, Hammon HM, Albrecht E, Setoguchi K, Takasuga A, Kuehn C: Metabolomic profiles indicate distinct physiological pathways affected by two loci with major divergent effect on Bos taurus growth and lipid deposition. Physiol Genomics 2010 42A:79-88.

45. Casas E, Shackelford SD, Keele JW, Koohmaraie M, Smith TPL, Stone RT: Detection of quantitative trait loci for growth and carcass composition in cattle. J Anim Sci 2003, 81:2976-2983.

46. McClure MC, Morsci NS, Schnabel RD, Kim JW, Yao P, Rolf MM, Mckay SD, Gregg SJ, Chapple RH, Northcutt SL, Taylor JF: A genome scan for quantitative trait loci influencing carcass, post-natal growth and reproductive traits in commercial Angus cattle. Anim Genet 2010, 41:597-607.

47. Knott SA, Elsen JM, Haley CS: Methods for multiple-marker mapping of quantitative trait loci in half-sib populations. Theor Appl Genet 1996, 93:71-80.

48. Morris CA, Bottema CDK, Cullen NG, Hickey SM, Esmailizadeh AK, Siebert BD, Pitchford WS: Quantitative trait loci for organ weights and adipose fat composition in Jersey and Limousin back-cross cattle finished on pasture or feedlot. Anim Genet 2010, 41:589-596.

49. Mashek DG, Li LO, Coleman RA: Long-chain acyl-CoA synthetases and fatty acid channeling. Future Lipidol 2007, 2:465-476.

50. Li LO, Ellis JM, Paich HA, Wang SL, Gong N, Altshuller G, Thresher RJ, Koves TR, Watkins SM, Muoio DM, Cline GW, Shulman Gl, Coleman RA: Liver-specific Loss of Long Chain Acyl-CoA Synthetase-1 Decreases Triacylglycerol Synthesis and beta-Oxidation and Alters Phospholipid Fatty Acid Composition. J Biol Chem 2009, 284:27816-27826.

51. Phillips CM, Goumidi L, Bertrais S, Field MR, Cupples LA, Ordovas JM, Defoort C, Lovegrove JA, Drevon CA, Gibney MJ, Blaak EE, Kiec-Wilk B, Karlstrom B, Lopez-Miranda J, McManus R, Hercberg S, Lairon D, Planells R, Roche HM: Gene-nutrient interactions with dietary fat modulate the association between genetic variation of the ACSL1 gene and metabolic syndrome. J Lipid Res 2010, 51:1793-1800.

52. Simopoulos AP: Genetic variants in the metabolism of omega- 6 and omega-3 fatty acids: their role in the determination of nutritional requirements and chronic disease risk. Exp Biol Med 2010, 235:785-795.

53. Itoh M, Johnson CB, Cosgrove GP, Muir PD, Purchas RW: Intramuscular fatty acid composition of neutral and polar lipids for heavy-weight Angus and Simmental steers finished on pasture or grain. J Sci Food Agric 1999, 79:821-827.

54. Choi NJ, Enser M, Wood JD, Scollan ND: Effect of breed on the deposition in beef muscle and adipose tissue of dietary $n-3$ polyunsaturated fatty acids. Anim Sci 2000, 71:509-519.

55. Tanaka K: Occurrence of conjugated linoleic acid in ruminant products and its physiological functions. Anim Sci J 2005, 76:291-303.

56. Herdmann A, Nuernberg K, Martin J, Nuernberg G, Doran O: Effect of dietary fatty acids on expression of lipogenic enzymes and fatty acid profile in tissues of bulls. Animal 2010, 4:755-762.

57. Malau-Aduli AEO, Siebert BD, Bottema CDK, Pitchford WS: A comparison of the fatty acid composition of triacylglycerols in adipose tissue from Limousin and Jersey cattle. Aust J Agric Res 1997, 48:715-722.

58. Kuehn C, Weikard R: An investigation into the genetic background of coat colour dilution in a Charolais $\times$ German Holstein F-2 resource population. Anim Genet 2007, 38:109-113.

59. Green P, Falls K, Crooks S: Documentation for CRIMAP. Version 24 (3/26/ 90) 1990.

60. Perez-Enciso M, Misztal I: Qxpak: a versatile mixed model application for genetical genomics and QTL analyses. Bioinformatics 2004, 20:2792-2798.

61. Nezer C, Moreau L, Wagenaar D, Georges M: Results of a whole genome scan targeting QTL for growth and carcass traits in a Pietrain $\times$ Large White intercross. Genet Sel Evol 2002, 34:371-387.

62. Elsik CG, Tellam RL, Worley KC, Gibbs RA, Abatepaulo ARR, Abbey CA Adelson DL, Aerts J, Ahola V, Alexander L, Alioto T, Almeida IG, Amadio AF, Anatriello E, Antonarakis SE, Anzola JM, Astashyn A, Bahadue SM, Baldwin CL, Barris W, Baxter R, Bell SN, Bennett AK, Bennett GL, Biase FH, Boldt CR, Bradley DG, Brinkman FSL, Brinkmeyer-Langford CL, Brown WC,
Brownstein MJ, Buhay C, Caetano AR, Camara F, Carroll JA, Carvalho WA Casey T, Cervelatti EP, Chack J, Chacko E, Chandrabose MM, Chapin JE, Chapple CE, Chen HC, Chen L, Cheng Y, Cheng Z, Childers CP, ChitkoMcKown CG, Chiu R, Choi JW, Chrast J, Colley AJ, Connelley T, Cree A, Curry S, Dalrymple B, ep Dao M, Davis C, de Oliveira CJF, de Miranda Santos IKF, de Campos TA, Deobald H, Devinoy E, Dickens CM, Ding Y, Dinh HH, De Donato M, Donohue KE, Donthu R, Dovc P, Dugan-Rocha S, Durbin KJ, Eberlein A, Edgar RC, Egan A, Eggen A, Eichler EE, Elhaik E, Ellis SA, Elnitski L, Ermolaeva O, Eyras E, Fitzsimmons CJ, Fowler GR, Franzin AM, Fritz K, Gabisi RA, Garcia GR, Garcia JF, Genini S, Gerlach D, German JB, Gilbert JGR, Gill CA, Gladney CJ, Glass EJ, Goodell J, Grant JR, Graur D, Greaser ML, Green JA, Green RD, Guan L, Guigo R, Hadsell DL, Hagen DE, Hakimov HA, Halgren R, Hamernik DL, Hamilton C, Harhay GP, Harrow JL, Hart EA, Hastings N, Havlak P, Henrichsen CN, Hernandez J, Hernandez M, Herzig CTA, Hiendleder SG, Hines S, Hitchens ME, Hlavina W, Hobbs M, Holder M, Holt RA, Hu ZL, Hume J, livanainen A, Ingham A, IsoTouru T, Jamis C, Jann O, Jensen $K$, Jhangiani SN, Jiang HY, Johnson AJ, Jones SJM, Joshi V, Junier T, Kapetis D, Kappes SM, Kapustin Y, Keele JW, Kent MP, Kerr T, Khalil SS, Khatib H, Kiryutin B, Kitts P, Kokocinski F, Kolbehdari D, Kovar CL, Kriventseva EV, Kumar CG, Kumar D, Lahmers KK, Landrum M, Larkin DM, Lau LPL, Leach R, Lee JCM, Lee S, Lemay DG, Lewin HA, Lewis LR, Li CX, Lien S, Liu GE, Liu YS, Liu Y, Logan KM, Lopez J, Lozado RJ, Lutzow YS, Lynn DJ, MacNeil MD, Maglott D, Malinverni R, Maqbool NJ, Marques E, Marra MA, Martin WF, Martins NF, Maruyama SR, Matukumalli LK, Mazza R, Mcewan JC, Mckay SD, Mclean KL, McWilliam S, Medrano JF, Memili E, Moen C, Molenaar AL, Moore SS, Moore R, More DD, Moreno BT, Morgan MB, Muntean CT, Muzny DM, Nandakumar HP, Nazareth LV, Nguyen NB, Nicholas FW, Nogueira MFG, Okwuonu GO, Olsaker I, Pant SD, Panzitta F, Pastor RCP, Patel BM, Payne GM, Plass M, Poli MA, Poslusny N, Pruitt K, Pu LL, Qin X, Rachagani S, Raison JM, Ranganathan S, Ratnakumar A, Razpet A, Reecy J, Reese JT, Ren Y, Reymond A, Riggs PK, Rijnkels M, Rincon G, Roberts A, Rodriguez-Osorio N, Rodriguez-Zas SL, Romero NE, Rosenwald A, Ruiz SJ, Sabo A, Salih H, Sando L, Santibanez J, Sapojnikov V, Schein JE, Schmutz SM, Schnabel RD, Schook L, Searle SM, Seo SW, Shen YF, Shen LB, Sherman L, Skow LC, Sonstegard TS: The Genome Sequence of Taurine Cattle: A Window to Ruminant Biology and Evolution. Science 2009, 324:522-528.

63. Zimin A, Delcher A, Florea L, Kelley D, Schatz M, Puiu D, Hanrahan F, Pertea G, Tassell C, Sonstegard T, Marcais G, Roberts M, Subramanian P, Yorke J, Salzberg S: A whole-genome assembly of the domestic cow, Bos taurus. Genome Biol 2009, 10:R42.

64. Oliphant A, Barker DL, Stuelpnagel JR, Chee MS: BeadArrayTM technology: Enabling an accurate, cost-effective approach to high-throughput genotyping. Biotechniques 2002, S56-S61.

65. Ye S, Dhillon S, Ke XY, Collins AR, Day INM: An efficient procedure for genotyping single nucleotide polymorphisms. Nucl Acids Res 2001, 29 : art-e88.

66. Liu KJ, Muse SV: PowerMarker: an integrated analysis environment for genetic marker analysis. Bioinformatics 2005, 21:2128-2129.

doi:10.1186/1471-2156-12-96

Cite this article as: Widmann et al.: Association of an ACSL1 gene variant with polyunsaturated fatty acids in bovine skeletal muscle. BMC Genetics 2011 12:96.

\section{Submit your next manuscript to BioMed Central and take full advantage of:}

- Convenient online submission

- Thorough peer review

- No space constraints or color figure charges

- Immediate publication on acceptance

- Inclusion in PubMed, CAS, Scopus and Google Scholar

- Research which is freely available for redistribution

Submit your manuscript at www biomedcentral.com/submit
C Biomed Central 